\title{
МЕДІАОСВІТА
}

Visn. Lviv. Univ., Ser. Zhurn. 2018: 44; 309-317 • DOI: http://dx.doi.org/10.30970/vjo.2018.44.9381

УДК 070:16:37.016

\section{ОСОБЛИВОСТІ ВИКЛАДАННЯ ЛОГІКИ ДЛЯ СТУДЕНТІВ-ЖУРНАЛІСТІВ}

\author{
Зіновій Партико \\ Інститут реклами, \\ вул. Фрометівська, 2 к. 2, Київ, 03039, Україна, \\ e-mail:partyko@ukr.net
}

Розглянуто особливості викладання логіки для студентів-журналістів, а також концепції істинності, які використовують у суспільстві. Для адекватного відтворення суспільних процесів у повідомленнях ЗМІ рекомендується доповнити традиційні теми матеріалом про механізми обгрунтування, багатозначними, ймовірнісними, а також модальними логіками.

Ключові слова: логіка, викладання, навчання, студенти, журналісти.

Постановка проблеми. Будь-яке суспільство вимагає, щоб у процесі його функціонування приймалися адекватні до поточної ситуації, обгрунтовані рішення. В іншому разі воно буде приреченим на вимирання або вкрай ускладнене існування, що веде до надмірних енергетичних затрат. Одним з основних інструментів для реалізації цієї вимоги в процесі навчання студентів природничих і технічних спеціальностей є математика. Для студентів гуманітарних і суспільних спеціальностей цю вимогу задовольняє логіка (ії замінник - інтуїтивна логіка - таку вимогу задовольняє вкрай недостатньо). Тому вивчення студентами цих наук належить до базових потреб суспільства. Такими міркуваннями визначається актуальність нашого дослідження.

Проблема, яку потрібно розв’язати в нашому дослідженні, полягає в з'ясуванні того, як потрібно викладати логіку для студентів гуманітарних і суспільних спеціальностей, зокрема спеціальності «Журналістика». Адже відомо, що мови сучасної символьної логіки (на зразок мови логіки предикатів, мови логіки висловів, мов багатозначних і модальних логік тощо) студенти гуманітарних, суспільних і мистецьких спеціальностей сприймають або з великими труднощами, або не сприймають узагалі. У цьому полягає перша частина проблеми. Друга частина проблеми полягає в тому, які теми подавати студентам гуманітарного профілю, враховуючи досягнення сучасної логіки, зокрема результати останнього століття, отримані в ділянках аргументації, багатозначних і модальних логік.

(C) Партико 3., 2018 
3 урахуванням сказаного, об'єктом нашого дослідження є логіка як наука. Предметом дослідження буде специфіка викладання цієї науки для студентів спеціальності «Журналістика». Тут під специфікою ми розуміємо, по-перше, методику подачі матеріалу для студентів-журналістів, які в переважній більшості $\epsilon$ носіями образного мислення, що часто базується на інтуїції; по-друге, методологічні засади цієї науки, зокрема трактування поняття істинності в ділянці суспільного життя; по-третє, апарати аргументації, який використовують у мас-медіа; по-четверте, види логік, які потрібно викладати майбутнім журналістам (з урахуванням появи в ХХ ст. багатозначних і модальних логік).

Метою дослідження $є$ вироблення рекомендацій для написання навчального видання з логіки для оптимального читання цієї дисципліни студентам-журналістам.

Для досягнення цієї мети були визначені такі завдання:

- провести огляд навчальних видань 3 логіки для студентів різних спеціальностей;

- запропонувати методику подачі матеріалу для навчальних видань 3 логіки для студентів-журналістів;

- сформулювати вимоги, яким повинно відповідати навчальне видання з логіки для студентів-журналістів;

- відібрати доступні навчальні видання з логіки, які варто рекомендувати для вивчення студентам-журналістам.

Виходячи з викладеного, стаття має теоретичний характер.

Аналіз останніх досліджень. Оскільки мова йде про навчальні видання, причому доступні студентам в Україні, то пошук було обмежено електронним каталогом НБ України ім. В. І. Вернадського. Серед навчальних видань з логіки, доступних зараз в Україні, в тому числі й через інтернет [1-33], можна виділити кілька груп: а) універсальні видання з традиційної логіки, в яких використовують напівформалізовану мову традиційної двозначної логіки на зразок $[1,10,27,30,32]$; б) спеціалізовані видання, тобто видання для окремих спеціальностей (юридичних, економічних тощо), в яких помірно використовують мови символьних логік та графічну інтерпретацію матеріалу [2, 7, 12, 29, 31]; в) спеціалізовані видання для математичних і кібернетичних спеціальностей, в яких максимально використовують мови символьних логік $[9,19,21,33]$; г) спеціалізовані видання для гуманітарних і суспільних спеціальностей, в яких не використовують або використовують украй помірно мови символьних логік $[4,14,15,25]$. Серед останньої групи видань в Україні доступні російські видання для гуманітаріїв $[4,15]$, а також спеціалізовані навчальні видання для студентів-журналістів $[14,25]$.

Як засвідчили результати інформаційного пошуку, в Україні спеціалізованого навчального видання для гуманітарних і суспільних спеціальностей (у тому числі й журналістикознавчих) немає. Приємним винятком є монографія [26]. Вказаний факт підтверджує необхідність і актуальність розв'язання вказаної у вступі проблеми.

\section{Виклад основного матеріалу.}

Методи дослідження. Для проведення дослідження буде застосовано такі методи:

- порівняння (для зіставлення вимог до логіки в різних спеціальностях);

- аналіз традиційний (для аналізу публікацій ЗМІ з позиції логіки);

- логічний метод (для з'ясування апаратів логіки та операцій логіки, які потрібні студентам-журналістам); 
Партико 3.

- синтез (для вироблення рекомендацій щодо специфіки читання логіки для студентів-журналістів).

Відмінності в застосуванні апаратів логіки студентами-журналістами стосовно інших спеціальностей. Якщо порівняти, для прикладу, викладання поняття істини студентам-математикам у математичній логіці й студентам-журналістам у традиційній логіці, то стає зрозумілим, що студентам-математикам поняття істини викладають у формі припущень, практично не розглядаючи конкретних ситуацій. На відміну від них, студентам-журналістам поняття істини викладають з урахуванням суті цього питання не тільки в природничих науках, а й з урахуванням поняття істини в суспільстві, зокрема і в інформаційних війнах, де істинність залежить від ступеня переконаності суб'єкта.

Крім того, в процесі аргументування студентам-журналістам часто доводиться використовувати такий механізм аргументування як обгрунтування, який у математичних, кібернетичних і природничих науках або не використовують, або використовують украй обмежено.

Якщо студенти-програмісти задовольняються двозначною математичною логікою, то студентам-журналістам украй бажано знати й інші види логік (багатозначні, модальні), оскільки їм часто доводиться описувати ті ділянки суспільного життя, які моделюють саме ці логіки, причому навіть такі як логіка оцінок, які описують апріорі нечіткі об’єкти, наприклад твори мистецтва.

Методика подання матеріалу студентам-журналістам. Як правило, студентам, що вивчають формальні науки (математика, кібернетика), читають двозначну логіку, виклад якої базується на символьних мовах і проведенні логічних числень з умовними значеннями істинності тверджень. Приблизно так само читають двозначну логіку студентам-юристам, але вже зі значно нижчим рівнем вивчення символьних мов $\mathrm{i}$ конкретними значеннями істинності. Традиційно таку логіку, але з мінімальним використанням символьних мов, читають і студентам-журналістам. Проте, виходячи 3 потреби описувати життя суспільства у всій його багатогранності, яка виходить далеко за межі двозначної логіки, викладання логіки студентам-журналістам повинно суттєво відрізнятися від вказаних спеціальностей.

Як уже зазначалося, в процесі викладання доводиться враховувати, що студенти-журналісти з труднощами сприймають мову символьної логіки, а тому її застосування під час викладання необхідно звести до мінімуму. 3 урахуванням сказаного, під час викладання і написання навчальних видань для студентів-журналістів доводиться застосовувати такі методичні прийоми:

- подавати матеріал практично без застосування символьних мов, тобто без формул;

- максимально використовувати найрізноманітніші графічні моделі на зразок діаграм Венна;

- викладати матеріал з ілюструванням на основі готових текстових прикладів або зразків чи шаблонів;

- для логічних «числень» рекомендувати користуватися таблицями, що містять готові рішення чи результати.

Трактування істинності в 3МІ. Розглянемо особливості трактування поняття істинності для студентів-журналістів. 
Істину визначають як таку властивість твердження, за якої воно адекватно ${ }^{1}$ відображає якийсь фрагмент реального світу, причому незалежно від специфіки цього відображення в свідомості суб'єкта (суб'єктів) пізнання й органів його (їх) чуття. Поняття істинності стосується не тільки тверджень, а й понять, але лише в тому разі, якщо подано їх означення.

Сформульоване визначення істинності вважається класичним. Іноді таку концепцію істинності називають ще кореспондентською на тій підставі, що зі зміною ситуації в світі, щоб залишатися істинним, повинно змінюватися й саме твердження, яке його описує, тобто твердження повинно кореспондуватися (видозмінюватися) разом $з$ дійсністю.

У математичній логіці використовують умовне визначення істинності. Воно базується на тому, що для якихось певних умов (ситуацій) припускають, що якесь абстрактне твердження є істинним.

Класичне означення істинності для логіки є цілком достатнім і традиційна логіка ним, як правило, задовольняється. Проте в суспільстві й, відповідно, в засобах масової інформації використовують низку інших концепцій істинності - мультиваріантну, конвенціональну, когерентну, прагматичну й нігілістичну.

Мультиваріантна концепція істинності була запропонована в Середні віки Фомою Аквінським. Вона полягає в тому, що істиною визнають одночасно і наукові, i релігійні істини.

У конвенціональній концепції істинності вважають, що істиною є те, з чим погоджується суспільство або його обрана («експертна») частина. Підвидом такої концепції $є$ авторитарна концепція істинності, що дає право на з'ясування істини лише тій частині суспільства, яка є владою (такими були, наприклад, більшовицький чи нацистський режими).

У когерентній концепції істинності вважають, що істинними є твердження такого повідомлення, між твердженнями якого немає протиріччя або суперечності. Тому, наприклад, якщо ми маємо навіть казку, в якій Котигорошко булавою вбиває семиголового Змія (основне, - щоб у ній ніде не було сказано, що Змій має іншу, ніж сім, кількість голів), то така казка є істинною, а, отже, і всі їі твердження також вважають істинними.

У прагматичній концепції істинності вважають, що істинною є така теорія, яка має прагматичну цінність, тобто є корисною для суспільної практики, дає позитивний результат. Так, істинною згідно з цією концепцією вважають, наприклад, теорію особистості 3. Фройда, яку широко використовують у психіатрії, хоча перевірити їі істинність у повному обсязі на емпіричному матеріалі відповідно до вимог науки неможливо.

У нігілістичній концепції істинності вважають, що істини як такої, оскільки довкола всі брешуть ${ }^{2}$, в реальному світі не існує. Істина існує лише в якомусь іншому можливому світі. Отже, говорити про те, що будь-яке твердження є істинним - безглуздо. Звідси випливає наслідок: оскільки все висловлене є брехнею, то говорити

\footnotetext{
${ }^{1}$ Основою для визначення ступеня адекватності слугують теорія подібності та застосовуваний у ній критерій подібності (між фрагментом світу та його віртуальною моделлю, відтвореною в значенні твердження). На побутовому рівні людина часто визначає ступінь подібності інтуїтивно.

2 Попередньо має бути введена саме така установка
} 
можна абсолютно все (адже воно і так, і сяк є хибним!), що й стає основою всіх повідомлень. Тим більше, що перевірити абсолютно всі твердження повідомлень ЗМІ реципієнти в принципі не мають змоги. Таку концепцію істинності під час інформаційних війн для виправдання власної хибної інформації використовують деякі держави, під час гостроконфліктних політичних переговорів - деякі сторони конфлікту тощо.

Особливості аргументації в 3МІ. Доведення й спростування є класичними методами аргументування. Проте в суспільній практиці, в тому числі й у повідомленнях 3MI, в якості аргументування часто доводиться використовувати зовсім інший механізм, який називають обгрунтуванням. На жаль, у навчальних виданнях 3 логіки цей механізм практично не описують.

Обгрунтування - це процедура представлення таких необхідних і достатніх аргументів, які дають змогу прийняти певне твердження (тобто тезу, яку аргументують). Його застосовують лише тоді, коли про твердження, яке обрають, не можна сказати, що вони ні істинне, ні хибне. Така ситуація зустрічається в юриспруденції, коли обирають серед норм; в економічних науках, коли критерієм якогось рішення обирають величину прибутку; в технічних і суспільних науках, коли з кількох можливих рішень обирають оптимальне; в мистецтвознавстві, коли визначають і досліджують оцінки.

Виокремлюють два види обгрунтування: абсолютне й відносне.

Абсолютним називають обгрунтування, в якому подають такі переконливі й достатні аргументи, які змушують прийняти обгрунтовувану тезу. Будова абсолютного обгрунтування така: $A$ повинно бути прийняте внаслідок $C$. Приклад:

Художник Y є найбільшим митцем сучасності, оскільки про изе вказали 15 з

21 спеціальним чином відібраних експертів.

Відносним називають обгрунтування, в якому подають множину таких переконливих і достатніх аргументів, які дають змогу прийняти одну, кращу тезу ніж іншу, повністю або частково протилежну їй. Будова відносного обгрунтування така: Краще прийняти $A$, ніж B, внаслідок $C$. Приклад відносного обгрунтування з економіки:

Краще використовувати спосіб оподаткування $А$ ніж $B$, оскільки спосіб A, хоча й приносить дещзо мениий прибуток ніж спосіб $B$, проте веде до швидшого ніж за способу В зростання економіки, а, отже, в перспективі до більшого сумарного прибутку.

Види логік, використовуваних у ЗМІ. Виходячи з об’єкту, який описують журналісти (суспільного життя), різні сфери його існування моделюються не тільки дво-, три-, чотири-, а й загалом $n$-значною логікою. Іноді для опису якихось подій доводиться застосовувати й імовірнісну логіку. Відповідно, студенти-журналісти, яким доведеться описувати ці сфери життя суспільства, повинні знати основи цих логік.

Крім багатозначних та ймовірнісної логік, окремі сфери життя суспільства моделює низка модальних логік. Відповідно, студенти-журналісти повинні знати основи таких модальних логік:

- алетична (модальності: необхідно, можливо, випадково, неможливо);

- темпоральна, або часова (модальності: було, є, буде; раніше, одночасно, пізніше);

- епістемічна (модальності: а) доведено, нерозв'язно, спростовано; б) вірить (варіанти: переконаний, вважає, знає), сумнівається, заперечує (варіант: не вірить); в) істинно, хибно, невизначено); 
- деонтична, або логіка норм (модальності: обов'язково, дозволено, заборонено);

- аксіологічна, або логіка оцінок (модальності: а) добре, задовільно (варіант: байдуже), погано; б) краще, рівнозначно, гірше);

- акціональна, або логіка дії (модальності: бажає (варіант: має намір), діє, не діє, протидіє, утримується від дій);

- логіка переваг (модальності: краще, рівнозначно, гірше);

- логіка змін (модальності: ще нема, виникає, вже $\epsilon$, ще $\epsilon$, зникає, вже нема);

- каузальна, або причинова логіка (модальності: причиново, невизначено причиново, непричиново).

У наш час відбувається інтенсивний розвиток цього напряму логічних досліджень. Останніми десятиліттями до цього напряму долучається і так звана паранесуперечлива логіка. Вона моделює таку ситуацію, відповідно до якої в суспільстві існують люди, які одночасно мають суперечливі світогляди чи вірування (наприклад, вірять у комунізм, але хочуть жити при капіталізмі).

Інтерпретація результатів дослідження. В Україні спеціальних навчальних видань 3 логіки для студентів-журналістів немає. Наявне монографічне видання [26] заявленим у цій статті потребам відповідає лише частково.

Наявні зразки видань інших держав мають як позитивні сторони, так і певні недоліки. Так, видання [4], хоча й призначено для гуманітаріїв, проте за фактом має надто багато матеріалу в формі символьної логіки, а також занадто розлогі діалогічні відступи. Видання $[14,15]$ мають композиційну будову, яка не зовсім збігається 3 традиційним університетським переліком тем логіки, хоча має легкий, доступний виклад, а також частково подає матеріал сучасних модальних логік. Книга [25] має найбільш прийнятний для студентів-журналістів виклад, проте не подає різні концепції істинності, механізми обгрунтування, а також багатозначні, імовірнісну й модальні логіки.

З урахуванням сказаного, слід констатувати, що в Україні для студентів-журналістів з логіки за аналогією до інших країн доцільно підготувати спеціальне навчальне видання.

Висновки. 1. У наш час для вивчення логіки студентам-журналістам доцільно рекомендувати видання $[4,14,15,25]$, які розраховані на вказану читацьку (гуманітарну) аудиторію та враховують методичні вимоги щодо подання матеріалу, зокрема його складності й застосування мов символьної логіки. Виклад матеріалу у цих виданнях доцільно доповнити матеріалом про концепції істинності, про методи обгрунтування, а також про багатозначні, імовірнісну та модальні логіки.

2. Оскільки видання $[4,14,15,25]$ написані недержавною мовою, не містять в одному виданні всіх потрібних тем, виникає потреба підготувати спеціалізоване навчальне видання для студентів-журналістів українською мовою з урахуванням запропонованих рекомендацій. Як тимчасовий допоміжний паралельний засіб доцільно використовувати монографію [26], що містить багато ілюстративного матеріалу з практики 3MI.

3. Читання дисципліни «Логіка» доцільно розподілити так, щоб традиційну двозначну логіку викладали бакалаврам (бажано на першому році навчання), а багатозначні, імовірнісну й модальні логіки, еристику - магістрам. 


\section{REFERENCES}

1. Асмус, В. Ф. Логика : учебник. - Москва : Государственное издательство политической литературы, 1947. - 388 с.

2. Бандурка, О. М. Юридична логіка : підручник. - Харків : Золота миля, 2011. $224 \mathrm{c}$.

3. Бондар, Т. І. Логіка : навч. посібник. - Київ : Слово, 2011. - 272 с.

4. Брюшинкин, В. Н. Практический курс логики для гуманитариев : учеб. пособие. - Москва : Новая школа, 1996. - 320 с.

5. Гасяк, О. С. Практична логіка. Алгоритми і зразки розв'язкових процедур : навч. посібник. - Чернівці : Рута, 2008. - 320 с.

6. Гасяк, О. С. Формальна логіка. Розв’язкові процедури, алгоритми, словник базових термінів і понять : навч. посібник. - Вид. 2-ге, перероб. і допов. - Чернівці : Рута, 2015. - 544 с.

7. Гладунський, В. Н. Логіка для студентів економічних спеціальностей : навч. посібник. - Львів : Афіша, 2002. - 360 с.

8. Гусев, Д. А. Краткий курс логики: Искусство правильного мышления. - Москва : Изд-во НЦ ЭНАС, 2003. - 192 с.

9. Дрозд, Ю. А. Основи математичної логіки : курс лекцій. - Київ : Київ. ун-т, 2005. $126 \mathrm{c}$.

10. Дуцяк, I. З. Логіка : підручник. - Київ : Знання, 2010. - 406 с.

11. Ерышев, А. А., Лукашевич, Н. П., Сластенко, Е. Ф. Логика : курс лекций. - 5-е изд. - Киев : МАУП, 2004. - 216 с.

12.Жеребкін, В. Є. Логіка : підручник. - 11-те вид., виправл. - Київ : Знання, 2011. $264 \mathrm{c}$.

13. Жоль, К. К. Логика : учеб. пособие. - Москва : ЮНИТИ-ДАНА, 2004. -400 с.

14. Ивин, А. А. Логика для журналистов : учеб. пособие. - М.: Аспект Пресс, 2002. $224 \mathrm{c}$.

15. Ивин, А. А. Логика : учебник для гуманитарных факультетов. - Москва : Гранд, ФАИР-ПРЕСС, 2002. - 318 c.

16. Карамишева, Н. В. Логіка (теоретична і прикладна) : навч. посібник. - Київ : Знання, 2011. -455 с.

17. Комарницький, М. Я. Елементи математичної логіки та теорії рекурсії : навч. посібник. - Львів : ЛНУ ім. Івана Франка, 2013. - 282 с.

18. Конверський, А. Є. Логіка (традиційна та сучасна) : підручник. - Київ : Центр учбової літератури, 2008. - 536 с.

19. Кривий, С. Л. Вступ до некласичної математичної логіки : навч. посібник. - Київ : Київський ун-т, 2010. - 206 с.

20. Логіка в таблицях і схемах : навч. посібник. - Рівне : Тетіс, 2010. - 112 c.

21. Нікітченко, М. С. Математична логіка та теорія алгоритмів : підручник. - Київ : Київський університет, 2008. - 528 с.

22. Нікітченко, М. С. Прикладна логіка : навч. посібник. - Київ : Київський університет, 2013. $-278 \mathrm{c}$.

23. Павлов, В. І. Логіка у запитаннях, відповідях і аргументаціях : навч. посібник. Київ : Центр учбової літератури, 2008. - 408 с. 
24.Рузавин, Г. И. Логика и аргументация. - Москва : Культура и спорт, ЮНИТИ, 1997. - $351 \mathrm{c.}$

25. Свинцов, В. И. Логика : учебник. - Москва : Высшая школа, 1987. - 287 с.

26. Скуленко, М. І. Логічні засади пропаганди : монографія. - Запоріжжя : Вид-во КПУ, 2010. - $312 \mathrm{c}$.

27. Тофтул, М. Г. Логіка : підручник. - 2-ге вид. - Київ : Академія, 2008. - 400 с.

28. Уёмов, А. И. Основы практической логики с задачами и упражнениями. Одесса: Одесский государственный университет им. И.И. Мечникова, 1997. 388 с.

29. Фармакологія - Cito!: фармакологічна логіка : підручник. - Харків : Тітул, 2015. $232 \mathrm{c}$.

30. Формальная логика : учебник. - Ленинград : Издательство Ленинградского университета, 1977. - 362 с.

31. Хоменко, І. Логіка - юристам : підручник. - Київ : Четверта хвиля, 1997. - 392 с.

32. Челпанов, Г. И. Учебник логики. - Москва : Госполитиздат, 1947. - 160 с.

33. Шкільняк, С. С. Математична логіка. Основи теорії алгоритмів : навч. посібник.Київ : Персонал, 2009. - 280 с. 


\title{
PECULIARITIES FOR TRAINING OF LOGIC FOR STUDENTS-JOURNALISTS
}

\author{
Zinovii Partyko \\ Institute of Advertising, \\ Frometivska Str. 2 p. 2, 79044, Kyiv, Ukraine \\ e-mail:partyko@ukr.net
}

The problem that it is necessary to solve is: how to teach logic for students of humanities and social disciplines, including speciality «Journalism».

The results of information retrieval in Ukraine certified that there are no specialized academic publications on logic for humanities and social specialities (including speciality «Journalism»). However, these educational editions are in some neighboring countries.

During teaching and writing educational books for students of journalism there is a need to use next principles: a) to state material almost without the use of symbolic languages, i.e. without formulas; b) to state material with graphical models, such as Venn diagrams; c) teaching material that is based on illustrations of the text samples or examples or templates; d) recommend to conduct logical «calculus» using the tables that contain ready-made solutions or results.

The concept of truth should be taught to student-journalists considering its essence not only in science but also considering its conceptions in society, including in the information war, where truth depends on degree of conviction of the individual. These social concepts of truth are multivariate, conventional, coherent, pragmatic and nihilistic.

During practical training in media, students-journalists use such kinds of argumentation as proof and disproof but often have to use this additional mechanism as a substantiation.

For students-journalists, in addition to the traditional two-valued logic, need to know and other logic (multivalued, probabilistic, modal), because they often have to describe those areas of social life which are modeled by these logics.

Conclusion: as textbooks on logic that satisfy the above requirements in Ukraine does not exist, the article recommend educational publications of other countries (the list is proposed), and concludes on the need to prepare this academic publications in Ukraine. In addition, the reading of the discipline «Logic» should be distributed in such a way that traditional two-valued logic is taught to bachelors, and multivalued, probabilistic and modal logics, and also eristic is taught to masters.

Key words: logic, learning, training, students, journalists. 